\title{
Strategies for Success: Open Access Policies at North American Educational Institutions
}

\section{Christine Fruin and Shan Sutton}

\begin{abstract}
Recognizing the paucity of quantitative and qualitative data from North American educational institutions that have pursued open access policies, the authors devised a survey to collect information on the characteristics of these institutions, as well as the elements of the open access policies, the methods of promoting these policies, faculty concerns about the policies, and how those concerns have been addressed. The data collected through survey results from fifty-one institutions can inform the strategic decisions being made by other institutions considering an open access policy and illustrates the essential roles that academic libraries can play in the development and passage of open access policies.
\end{abstract}

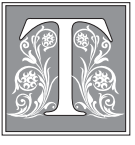

he establishment of open access policies at North American universities and colleges can be traced back to 2008 when open access emerged as a viable topic of policy development. At that time, the National Institutes of Health (NIH) enacted a policy requiring all published research funded by the NIH to be available in the publicly accessible database PubMed within twelve months of commercial publication. ${ }^{1}$ That same year, Harvard University's College of Liberal Arts and Sciences became the first North American institution to enact an open access policy, which granted Harvard a nonexclusive license to make the scholarly works of the faculty in that college available for noncommercial use through Harvard's institutional repository. ${ }^{2}$ More recently, most of the major federal funding agencies impacted by the 2013 executive order by the White House Office of Science and Technology Policy directing the development of public access plans have adopted such plans. At the state government level, California, Illinois, and New York have proposed or enacted laws to ensure public access to publicly funded research. ${ }^{3}$

Meanwhile, well over fifty educational institutions, including MIT, Duke University, and the University of California system, have enacted or are in the process of developing open access policies at institutional, college, and departmental levels. ${ }^{4}$ To support these institutions, the Coalition of Open Access Policy Institutions was formed in 2011 to share information and illuminate opportunities for moving faculty-led open access policies forward at member institutions and advocate for open access nationally and internationally. ${ }^{5}$ Further, the persons instrumental in drafting and implementing the Harvard open access policy have released a living

Christine Fruin is Scholarly Communications Librarian at University of Florida; e-mail: christine.ross@ ufl.edu. Shan Sutton is Vice Dean of University Libraries at University of Arizona; e-mail: ssutton@email. arizona.edu. (C) 2016 Christine Fruin and Shan Sutton, Attribution-NonCommercial (http://creativecommons. org/licenses/by-nc/3.0/) CC BY-NC. 
document entitled "Good Practices for University Open-Access Policies," which includes recommendations to address common open access misconceptions, policy terms to include or avoid, and strategies for policy implementation. ${ }^{6}$ These recommendations stem from the experiences of Harvard and institutions that have adopted a Harvard-style policy. However, additional quantitative and qualitative data from institutions that have enacted or are in the midst of drafting policies are needed to better inform the strategic decisions being made by institutions considering an open access policy. These data are also needed to better understand the essential roles that academic libraries have played in the development and passage of open access policies.

\section{Literature Review}

A review of the literature reveals a lack of a comprehensive study of North American institutions that have enacted or are planning to enact an open access policy. Only a handful of articles have been written in the last ten years by North American library practitioners on the topic of institutional open access policies, and these articles tend to either focus on a specific institution or on a single facet of open access policy implementation. In 2012, an Indiana University library and information science professor, along with a group of library science students, undertook a review of the language used in open access policies developed primarily by international organizations and the perceived effect of those policies on the repository deposit rate at those institutions. ${ }^{7}$ This study was not limited to educational institutions, nor was it limited to policies affecting faculty scholarship. A large portion of its review concerns policies mandating deposit of theses and dissertations, which is a very different type of policy than the ones surveyed here.

Three of the articles that were reviewed touch on many of the areas of this survey by detailing the process of policy promotion and adoption at three institutions where open access policies have been adopted. University of Kansas (KU) librarian Ada Emmett and her colleagues describe in detail the climate at KU prior to the proposal of an open access policy as well as the groups created and charged with drafting the policy and promoting it to faculty. The article also reflects upon the concerns raised by KU faculty and how the library and groups charged with policy promotion have addressed those concerns in their responses and workflows. ${ }^{8}$ Kevin Smith, Duke University's Director of Scholarly Communications, similarly describes the environment at Duke University prior to the passage of its policy in 2010 and the process that was followed there to help ensure successful passage. ${ }^{9}$ Finally, Rice University librarian Shannon Kipphut-Smith reported on the methods of promoting an open access policy to faculty at Rice. Again, faculty concerns, similar to those explored in the survey here, were raised, and Kipphut-Smith shares how those concerns were addressed through outreach and service. ${ }^{10}$

Kipphut-Smith authored another article concerning open access policies, this time about how the Rice University library adopted a new workflow to collect and deposit faculty works in the institutional repository in compliance with the adopted open access policy. ${ }^{11}$ This article reinforces the importance of the library's role in open access policy adoption, particularly in addressing the concern by faculty that deposit of articles in the institutional repository poses a significant burden on them. Similarly, Allegheny College librarian Brian Kern also wrote about his library's role in advocating for an open access policy among faculty and also how that library implemented a workflow to direct faculty scholarship into its institutional repository. ${ }^{12}$

While some of the major themes in the professional literature are also reflected in the survey underpinning this article, none of the existing literature encompasses the 
multi-institutional nature of this study. Analysis of the survey results offers a unique, cross-institutional perspective that greatly enhances the single-institution viewpoints typically found in articles on open access policies. It also further illuminates the academic library's role in open access policymaking. The next section reviews the survey results, followed by an analysis of selected issues that were raised by the results.

\section{Method}

To capture these data, the authors devised a survey to collect information on the characteristics of institutions that have enacted, attempted to enact, or are considering open access policies, as well as the elements of these policies and the methods of promoting the policies, including faculty concerns and how those concerns have been addressed. The survey was designed in Qualtrics and included five sections of questions. The survey draft was reviewed and tested by open access policy experts who provided feedback on the survey design and content. In August 2014, the authors, via several listservs, requested North American institutions to respond to the survey. The responses from the fifty-one institutions that completed the survey reveal the key strategies employed in conceiving, promoting, and implementing open access policies and illustrate how libraries often play a key role in the policymaking process. ${ }^{13}$

Two sections were answered by all respondents; these sections polled them on the demographics of their institutions and the status of open access policy development at the responding institution. Depending on the response to the question on policy status, respondents were directed to one of the three remaining sections. Each of these remaining sections contained questions tailored to the state of open access policy development at the time the survey was answered. There was a section for those that had passed a policy ("Enacted Policy Group"), those with a policy currently under consideration ("In Process Policy Group"), and those that had failed to pass a policy ("Failed Policy Group"). The questions in each section polled respondents on policy development methodology, waivers, embargoes, policy promotion, and their experience in receiving and responding to faculty concerns.

\section{Results}

\section{Demographics}

Fifty-one educational institutions from the United States and Canada responded to the survey. A review of the demographics of the fifty-one institutions does not reveal many points of homogeny. The survey respondents represent institutions of all sizes and profiles that have successfully pursued open access of their faculty's scholarship as a matter of policy. Of the responding institutions, 65 percent are public and 35 percent are private, with 16 respondents indicating that they were founded as land grant institutions.

Survey data reveal that the institutions vary in the size of their faculty, their federal research budgets, and their degree offerings as well. More than 50 percent of the survey respondents indicated that their institution received more than $\$ 100$ million in federal research funding, with 24 percent reporting that their institution received $\$ 500$ million or more. The size of respondents' faculty bodies also varied. The largest percentage of respondents (27\%) indicated that their faculty size was greater than 3,000; however, 25 percent of respondents had fewer than 500 faculty members. Further, while most of the respondents offer bachelor's, master's and doctoral degrees, only about half offer professional degree programs.

As part of the survey, respondents were asked about the governance model and faculty-administration relations at their campuses. Forty of the fifty-one respondents indicated that their faculty members were not covered by a collective bargaining agreement. The majority of the respondents (88\%) participate in shared governance 
at their campuses, with a similar percentage indicating that there was a library advising or consulting committee composed of faculty not affiliated with the library. However, perceptions varied as to how well this shared governance was working at individual campuses. The majority of the institutions with enacted policies reported a collaborative, collegial, and otherwise positive relationship between faculty and administration. The two responding institutions where a policy measure failed also indicated that relationships were positive. Several respondents indicated that their campus was at a time of transition, most typically due to a new president or chancellor. Other respondents indicated that relationships between faculty and administration were variable, with reports of "suspicion" existing within certain pockets of faculty or differences among individual schools or colleges within a single institution.

\section{Open Access Policies}

\section{Policy Types}

As aforementioned, survey respondents fall into three groups: Enacted Policy Group, In Process Policy Group, and Failed Policy Group. The status of policy development at responding institutions is indicated in the table below.

\begin{tabular}{|c|c|}
\hline \multicolumn{2}{|c|}{ TABLE 1 } \\
Open Access Policy Status \\
\hline $\begin{array}{l}\text { Policy Status (by } \\
\text { institution type) }\end{array}$ & $\begin{array}{c}\text { Number of } \\
\text { Institutions }\end{array}$ \\
\hline Private Institutions & \\
\hline Enacted & 17 \\
\hline In Process & 1 \\
\hline Public Institutions & \\
\hline Enacted & 23 \\
\hline In Process & 8 \\
\hline Failed Policy & 2 \\
\hline
\end{tabular}

The survey offered respondents six different policy types to choose from to indicate the model that applies at each campus. There was also an option to select if a policy was a blend of different models, with a comments section to describe the blended model. In the Enacted Policy Group, 50 percent chose the model that automatically grants to the institution a nonexclusive license to faculty research articles, requires deposit of articles (or the final accepted manuscripts) to an institutional repository, and allows for waivers or other opt-out options. This so-called Harvard model was also involved in approximately half of the blended policy types that accounted for 23 percent of the total responses of the Enacted Policy Group. The second most common policy type after the Harvard model was a general statement of encouragement to faculty to publish their future works through open access vehicles.

Respondents in the In Process Group were spread evenly between the Harvard model, blended models, and statements of encouragement to disseminate articles through open access. In the Failed Policy group, both respondents had pursued a statement of encouragement to publish via open access.

\section{To Whom the Policy Applies}

Open access policies vary in terms of application. Institutional-level policies cover all faculty members; however, some policies have alternatively been established at the department or college level. The survey results demonstrate that most respondents have pursued institutional policies covering all faculty authors. In the Enacted Policy Group, 73 percent had this type of policy in place, while 78 percent of the In Process Group were planning this kind of policy; and both schools in the Failed Policy Group had attempted to pass an institutional policy. 


\begin{tabular}{|c|c|c|c|c|}
\hline \multicolumn{5}{|c|}{$\begin{array}{c}\text { TABLE } 2 \\
\text { Open Access Policy Types }\end{array}$} \\
\hline Policy Type & $\begin{array}{c}\text { Policy } \\
\text { Enacted }\end{array}$ & $\begin{array}{l}\text { Policy in } \\
\text { Progress }\end{array}$ & $\begin{array}{l}\text { Policy } \\
\text { Failed }\end{array}$ & $\begin{array}{c}\text { Percentage } \\
\text { of Total } \\
\text { Responses }(\%)\end{array}$ \\
\hline $\begin{array}{l}\text { Policy grants, without action by the } \\
\text { author, the institution certain non- } \\
\text { exclusive rights (a pre-existing license) } \\
\text { to future research articles published by } \\
\text { faculty and offers a waiver or an opt-out } \\
\text { for authors. The policy also requires } \\
\text { deposit in the institutional repository. }\end{array}$ & 19 & 2 & 0 & $41 \%$ \\
\hline $\begin{array}{l}\text { Policy requires faculty to negotiate with } \\
\text { publishers to retain certain non-exclusive } \\
\text { rights in their articles including the right } \\
\text { to deposit their articles in the institutional } \\
\text { repository. }\end{array}$ & 1 & 1 & 0 & $.04 \%$ \\
\hline $\begin{array}{l}\text { Policy seeks no rights at all but requires } \\
\text { faculty to deposit future articles in the } \\
\text { institutional repository. Deposits will be } \\
\text { available immediately upon deposit if } \\
\text { institution has permission from author to } \\
\text { make it available open access. Otherwise, } \\
\text { deposit will be dark. }\end{array}$ & 1 & 0 & 0 & $.02 \%$ \\
\hline $\begin{array}{l}\text { Policy seeks no rights at all and requires } \\
\text { deposit in the institutional repository and } \\
\text { open access availability only when the } \\
\text { publisher permits it. }\end{array}$ & 1 & 1 & 0 & $.04 \%$ \\
\hline $\begin{array}{l}\text { Policy is merely a statement of } \\
\text { encouragement to publish future works } \\
\text { open access. }\end{array}$ & 5 & 2 & 2 & $14 \%$ \\
\hline $\begin{array}{l}\text { Policy does not require open access but } \\
\text { asks faculty to "opt in" to the practice of } \\
\text { self archiving and open access. }\end{array}$ & 3 & 2 & 0 & $10 \%$ \\
\hline $\begin{array}{l}\text { If your policy is of a type not described } \\
\text { here, or is a blend of two or more of } \\
\text { these policy types, please detail the } \\
\text { general conditions of the policy enacted } \\
\text { at your institution. }\end{array}$ & 9 & 2 & 0 & $22 \%$ \\
\hline
\end{tabular}

Among those institutions focused on department- or college-level policies, the library is typically the unit for which the policy is being developed. For respondents who have passed a department or college policy, 63 percent involved the library; and, within the In Process Group, 100 percent of the department- or college-level policies were directed at librarians. Examples of nonlibrary departments or schools with open access policies include College of Arts and Sciences, School of Public Health, Graduate School of Social Work, and School of Engineering. 


\section{Process Used to Establish the Policy}

Whether a policy is at the institutional or department/college level, the method of approval nearly always involves a vote by the faculty. Eighty-eight percent of the respondents within the Enacted Policy Group indicated that a vote was held in either the faculty senate (or comparable institutionwide faculty body) or within a department/college. The remaining 12 percent employed some combination of faculty vote and administrative action. Comparable numbers were found in the other respondent groups, with 67 percent of the In Process Group planning a faculty senate vote, and the remaining 33 percent pursuing a strategy using both faculty voting mechanisms and administrative actions. Both respondents in the Failed Policy Group held an unsuccessful faculty senate vote.

The faculty senate votes in the Enacted Policy group registered impressive margins. Fifty-four percent were unanimous, while an additional 35 percent were more than 90 percent. Another 3 percent registered a solid majority of $60-90$ percent, and 8 percent resulted in a slight majority outcome of 51-59 percent.

\section{Waivers and Embargoes}

Most policies (86 percent in the Enacted Policy Group and 67 percent in the In Process Group) include language that grants automatic waivers to a faculty author on request without justification or explanation. In the majority of policies at institutions surveyed, the waiver is granted on a per-article basis, rather than a blanket waiver for all of a faculty member's articles. In some cases, the waiver applies to both the nonexclusive license and the requirement to deposit into the institutional repository, while in others it applies to the license only and faculty members are still expected to deposit all of their article manuscripts.

Respondents were also asked if they observe publisher embargoes that seek to dictate when open access versions of articles can be made publicly available. Seventy percent of respondents in the Enacted Policy Group honor publisher embargoes in spite of the fact that most have nonexclusive license policies in place that should supersede any publisher-imposed restrictions. In this same group, 10 percent do not observe publisher embargoes and 20 percent do in some cases, mostly at the request of authors. Within the In Process Group, the responses on honoring publisher embargoes were 56 percent yes, 11 percent no, and 33 percent undecided.

\section{Policy Origination and Promotion}

\section{Who Conceived and Promoted the Policy}

The survey asked participants to describe how the idea of an open access policy arose and who first raised the concept. In all three respondent groups, the vast majority of open access policies were initiated by the institutions' libraries. The individuals within the library who conceived the policy varied, with responses naming the library dean/ director, scholarly communication librarian, scholarly communication committee, and other librarians as key figures. In some cases of institutionwide policies, the idea was initially raised by people outside the library, such as the Vice President for Research, "activist faculty" in various departments, or a committee appointed by the Provost. Although the library typically played a lead role in initiating open access policies, respondents indicated that they often worked in conjunction with other bodies connected to faculty senate, especially the senate's library committee.

Partnerships between academic libraries and faculty outside the library were also identified as a critical component of promoting the institutional policies across campus in advance of faculty votes. In all three respondent groups, the most common approach articulated by respondents was to assign responsibility for managing the promotion process to either the faculty senate library committee or a committee specifically formed to promote the policy. In some cases, the Provost's office or the Office of Research was directly involved in policy promotion. 
TABLE 3

Reasons Offered in Conversations with Faculty on Why Open Access is Important

\begin{tabular}{|c|c|c|c|c|}
\hline Reason & $\begin{array}{c}\text { Policy } \\
\text { Enacted }\end{array}$ & $\begin{array}{l}\text { Policy in } \\
\text { Progress }\end{array}$ & $\begin{array}{l}\text { Policy } \\
\text { Failed }\end{array}$ & $\begin{array}{c}\text { Percentage } \\
\text { of Total } \\
\text { Responses }(\%)\end{array}$ \\
\hline $\begin{array}{l}\text { Open access enables authors to retain more } \\
\text { of their rights in their own work rather than } \\
\text { assigning all rights to the publishers. }\end{array}$ & 34 & 7 & 1 & $82 \%$ \\
\hline $\begin{array}{l}\text { Open access is a means of addressing the pricing } \\
\text { crisis in subscription scholarly journals and } \\
\text { combating the monopoly that a few publishers } \\
\text { have on the dissemination of scholarship. }\end{array}$ & 24 & 3 & 2 & $57 \%$ \\
\hline $\begin{array}{l}\text { Open access promotes access to research by } \\
\text { anyone. It allows more people to benefit from } \\
\text { scholarship, including the general public who may } \\
\text { have an interest in or need for scholarly research. }\end{array}$ & 36 & 8 & 1 & $88 \%$ \\
\hline $\begin{array}{l}\text { Open access allows faculty to not only be better } \\
\text { researchers but also better educators. When } \\
\text { professors can't access the most recent research, } \\
\text { they are deprived of the opportunity to bring } \\
\text { that material into the classroom. With science } \\
\text { advancing at an ever-increasing pace, it's crucial } \\
\text { that professors have access to cutting-edge } \\
\text { research, so students' education is not outdated } \\
\text { before they even finish a course. }\end{array}$ & 15 & 2 & 1 & $35 \%$ \\
\hline $\begin{array}{l}\text { Open access facilitates collaboration on } \\
\text { new research. With access barriers removed, } \\
\text { scientists and other researchers can share } \\
\text { scholarship across borders and work together } \\
\text { more efficiently to bring forth new ideas. }\end{array}$ & 23 & 5 & 0 & $55 \%$ \\
\hline $\begin{array}{l}\text { Open access supports public access. A large } \\
\text { body of scholarship is funded through public tax } \\
\text { dollars, and the public should be allowed free } \\
\text { and unburdened access to the research they help } \\
\text { support. }\end{array}$ & 34 & 9 & 0 & $86 \%$ \\
\hline $\begin{array}{l}\text { Scholarly research can be made open access } \\
\text { through deposit in open access repositories } \\
\text { (green OA) or through publication in open } \\
\text { access journals (gold OA). Publication of } \\
\text { scholarly research in gold OA journals does not } \\
\text { signify that the research is of lesser quality. Gold } \\
\text { OA scholarly literature is not lesser quality than } \\
\text { traditionally published scholarship. Much of the } \\
\text { open access literature published via gold OA is } \\
\text { subject to the same or more rigorous peer review } \\
\text { as traditional toll access journals. }\end{array}$ & 25 & 7 & 0 & $63 \%$ \\
\hline $\begin{array}{l}\text { Open access supports the institution's land grant } \\
\text { mission. }\end{array}$ & 5 & 3 & 0 & $16 \%$ \\
\hline $\begin{array}{l}\text { Open access supports the institution's education } \\
\text { and/or research mission. }\end{array}$ & 34 & 5 & 1 & $78 \%$ \\
\hline
\end{tabular}


TABLE 3

Reasons Offered in Conversations with Faculty on Why Open Access is Important

\begin{tabular}{|l|c|c|c|c|}
\hline Reason & $\begin{array}{c}\text { Policy } \\
\text { Enacted }\end{array}$ & $\begin{array}{c}\text { Policy in } \\
\text { Progress }\end{array}$ & $\begin{array}{c}\text { Policy } \\
\text { Failed }\end{array}$ & $\begin{array}{c}\text { Percentage } \\
\text { of Total } \\
\text { Responses (\%) }\end{array}$ \\
\hline $\begin{array}{l}\text { Open access enables access to research by } \\
\text { scholars at institutions that cannot afford access } \\
\text { to the subscription-based journals in which the } \\
\text { articles are published, especially those in non- } \\
\text { Western countries. }\end{array}$ & 27 & 6 & 1 & $\mathbf{6 6 \%}$ \\
\hline $\begin{array}{l}\text { Open access to research outputs is becoming a } \\
\text { standard requirement at many funding agencies. }\end{array}$ & 20 & 8 & 0 & $\mathbf{5 5 \%}$ \\
\hline Other (Please detail below.) & 16 & 1 & 0 & $\mathbf{3 3 \%}$ \\
\hline $\begin{array}{l}\text { We didn't discuss with faculty and other } \\
\text { constituents the importance of open access. }\end{array}$ & 0 & 1 & 0 & $\mathbf{. 0 1 \%}$ \\
\hline
\end{tabular}

\section{Rationales for Open Access}

When promoting an open access policy to faculty, proponents articulate the values and benefits of open access. The survey results confirmed this as respondents were asked to identify which arguments they employed to convey the importance of open access. Choosing among a list of twelve options, most chose more than one reason to reflect a multipronged approach to the issue. The most frequently selected rationales in the Enacted Policy and In Process groups were:

- Open access enables authors to retain more of their rights in their own work rather than assigning all rights to the publishers.

- Open access promotes access to research by anyone. It allows more people to benefit from scholarship, including the general public who may have an interest in or need for scholarly research.

- Open access supports public access. A large body of scholarship is funded through public tax dollars, and the public should be allowed free and unburdened access to the research they help support.

There were substantial differences in how frequently the following reasons were selected by these two groups of respondents:

- Open access is a means of addressing the pricing crisis in subscription scholarly journals and combating the monopoly that a few publishers have on the dissemination of scholarship. (This reason was chosen by 65 percent of the Enacted Policy Group versus 33 percent of the In Process Group.)

- Open access supports the institution's education and/or research mission. (This reason was chosen by 90 percent of the Enacted Policy Group versus 56 percent of the In Process Group.)

- Open access to research outputs is becoming a standard requirement at many funding agencies. (This reason was chosen by 55 percent of the Enacted Policy Group versus 89 percent of the In Process Group.)

\section{Time Spent on Policy Promotion}

Survey participants were asked how much time was spent educating faculty about open access and the policy before it was presented for formal adoption. Among the three respondent groups, there was a strong tendency to indicate a timeframe of either six to twelve months, or one to two years. 


\begin{tabular}{|l|c|c|c|}
\hline \multicolumn{4}{|c|}{ TABLE 4 } \\
Time Spent Educating Faculty on Open Access and the Policy \\
\hline Amount of Time & Policy Enacted & Policy in Progress & Policy Failed \\
\hline Less than six months & $15 \%$ & $0 \%$ & $50 \%$ \\
\hline Six to twelve months & $33 \%$ & $44 \&$ & $50 \%$ \\
\hline One to two years & $31 \%$ & $44 \%$ & $0 \%$ \\
\hline More than two years & $21 \%$ & $12 \%$ & $0 \%$ \\
\hline
\end{tabular}

\section{Methods of Promotion}

Methods of promotion were similar across the three groups. Institutions in both the Enacted Policy Group and the In Process Group as well as both institutions in the Failed Policy Group reported that they did not rely upon any external resources when promoting an open access policy at their campus. For those that did rely upon external resources, several institutions relied on the Scholarly Publishing and Academic Resources Coalition (SPARC). Several also referred to materials available on the websites of other institutions that had enacted open access policies. Among the Enacted Policy Group, the people and resources at open access policy groundbreaker Harvard University were popular. A few respondents indicated that they had either in-person visits or consultations from Harvard open access proponents Peter Suber and Stuart Shieber. Institutions within the Enacted Policy Group also reported referring to materials put out by Harvard's Office of Scholarly Communication and the Harvard Open Access Project.

In addition to external resources, institutions in both the Enacted Policy Group and the In Process policy Group identified a variety of internally created resources to assist in their open access policy promotions. The most common internally based methods include:

- Websites, including LibGuides

- Brochures

- In-person meetings with faculty, including open forums, brown bag sessions, and departmental visits

- Targeted e-mails

- Articles in library and other campus newsletters

- Open Access Week programming on campus

\section{Faculty Concerns}

In the midst of the promotion of a policy, faculty affected by its terms often raise concerns about the perceived impact the policy will have on such issues as author choice in the journal of publication, academic freedom, rights retention, and publisher relations. The survey articulated these and several other concerns that are frequently raised by faculty and asked respondents to indicate which ones they had observed at their institutions. Below is a table summarizing the concerns that are most commonly raised by faculty about open access policies according to respondent observations at their institutions. The table indicates the percentage of those in each policy status group that indicated this concern had been expressed by affected faculty at their institutions.

The survey also asked respondents how they addressed the concerns expressed by faculty about an open access policy. In the survey, respondents were provided a list of potential responses they could give to faculty in reply to these concerns. The table below lists the responses to faculty concerns and the percentage of respondents who included these messages in their communications with faculty. 


\begin{tabular}{|l|c|c|c|c|}
\hline \multicolumn{5}{|c|}{ FAculty Concerns about Open Access Policies } \\
\hline Faculty Concern & $\begin{array}{c}\text { Policy } \\
\text { Enacted }\end{array}$ & $\begin{array}{c}\text { Policy in } \\
\text { Progress }\end{array}$ & $\begin{array}{c}\text { Policy } \\
\text { Failed }\end{array}$ & $\begin{array}{c}\text { Percentage } \\
\text { of Total } \\
\text { Responses (\%) }\end{array}$ \\
\hline $\begin{array}{l}\text { Complying with the policy will create } \\
\text { a burden on faculty }\end{array}$ & 30 & 7 & 1 & $\mathbf{7 5 \%}$ \\
\hline $\begin{array}{l}\text { Concern that control of copyright } \\
\text { being transferred to institution and that } \\
\text { deposit in IR permits unauthorized use } \\
\text { of works by others }\end{array}$ & 28 & 5 & 0 & $\mathbf{6 5 \%}$ \\
\hline $\begin{array}{l}\text { Belief that publishers will refuse work if } \\
\text { author subject to an open access policy }\end{array}$ & 26 & 6 & 1 & $\mathbf{6 5 \%}$ \\
\hline $\begin{array}{l}\text { Belief that a mandatory policy is an } \\
\text { act of institutional control or coercion }\end{array}$ & 21 & 6 & 1 & $\mathbf{5 5 \%}$ \\
\hline $\begin{array}{l}\text { Confusion about what types of works } \\
\text { the policy applies to }\end{array}$ & 23 & 3 & 1 & $\mathbf{5 3 \%}$ \\
\hline $\begin{array}{l}\text { Belief that open access will hurt } \\
\text { scholarly societies }\end{array}$ & 19 & 5 & 1 & $\mathbf{4 9 \%}$ \\
\hline $\begin{array}{l}\text { Belief that policy requires publication } \\
\text { in open access journals }\end{array}$ & 16 & 4 & 1 & $\mathbf{4 1 \%}$ \\
\hline $\begin{array}{l}\text { Belief that open access infringes upon } \\
\text { academic freedom }\end{array}$ & 18 & 2 & 0 & $\mathbf{3 9 \%}$ \\
\hline $\begin{array}{l}\text { Confusion of place of publication vs. } \\
\text { requirement of deposit in the IR }\end{array}$ & 13 & 2 & 0 & $\mathbf{2 9 \%}$ \\
\hline $\begin{array}{l}\text { Requirement of multiple deposits where } \\
\text { funder policy also requires deposit of } \\
\text { work in an open access repository. }\end{array}$ & 8 & 4 & 0 & $\mathbf{2 4 \%}$ \\
\hline
\end{tabular}

\begin{tabular}{|l|c|c|c|c|}
\hline \multicolumn{5}{|c|}{ TABLE 6 } \\
\hline Response to Faculty Concerns & $\begin{array}{c}\text { Policy } \\
\text { Enacted }\end{array}$ & $\begin{array}{c}\text { Policy in } \\
\text { Progress }\end{array}$ & $\begin{array}{c}\text { Policy } \\
\text { Failed }\end{array}$ & $\begin{array}{c}\text { Percentage } \\
\text { of Total } \\
\text { Responses (\%) }\end{array}$ \\
\hline $\begin{array}{l}\text { No requirement to publish in an open } \\
\text { access journal; article may be published } \\
\text { in any scholarly journal }\end{array}$ & 30 & 5 & 1 & $\mathbf{7 1 \%}$ \\
\hline $\begin{array}{l}\text { Outline many benefits of depositing } \\
\text { works in an institution repository }\end{array}$ & 31 & 5 & 1 & $\mathbf{7 1 \%}$ \\
\hline Deposit assistance available & 30 & 4 & 1 & $\mathbf{6 7 \%}$ \\
\hline $\begin{array}{l}\text { Clarification that the final version of } \\
\text { the peer reviewed manuscript, not the } \\
\text { published version, should be deposited }\end{array}$ & 27 & 5 & 1 & $\mathbf{6 5 \%}$ \\
\hline $\begin{array}{l}\text { Copyright ownership is not transferred } \\
\text { to the institution; rather, authors retain } \\
\text { copyright and grant the institution a } \\
\text { nonexclusive license }\end{array}$ & 26 & 6 & 1 & $\mathbf{6 5 \%}$ \\
\hline
\end{tabular}




\begin{tabular}{|l|c|c|c|c|}
\hline \multicolumn{5}{|c|}{ TABLE 6 } \\
\hline Response to Faculty Concerns & $\begin{array}{c}\text { Policy } \\
\text { Enacted }\end{array}$ & $\begin{array}{c}\text { Policy in } \\
\text { Progress }\end{array}$ & $\begin{array}{c}\text { Policy } \\
\text { Failed }\end{array}$ & $\begin{array}{c}\text { Percentage } \\
\text { of Total } \\
\text { Responses (\%) }\end{array}$ \\
\hline $\begin{array}{l}\text { Clarification that the policy only applies } \\
\text { to scholarly articles published after } \\
\text { policy's effective date }\end{array}$ & 27 & 5 & 0 & $\mathbf{6 3 \%}$ \\
\hline $\begin{array}{l}\text { Waiver available if publisher refuses to } \\
\text { publish on account of policy }\end{array}$ & 25 & 4 & 0 & $\mathbf{5 7 \%}$ \\
\hline $\begin{array}{l}\text { Waivers are available without proof or } \\
\text { justification of need }\end{array}$ & 24 & 3 & 0 & $\mathbf{5 3 \%}$ \\
\hline $\begin{array}{l}\text { Faculty members may elect an embargo } \\
\text { upon availability of their deposited works }\end{array}$ & 21 & 3 & 0 & $\mathbf{4 7 \%}$ \\
\hline $\begin{array}{l}\text { If work has been deposited in a funder } \\
\text { mandated repository, it will be harvested } \\
\text { by institution }\end{array}$ & 12 & 3 & 1 & $\mathbf{3 1 \%}$ \\
\hline $\begin{array}{l}\text { Library will track publication of articles } \\
\text { and request manuscripts from faculty for } \\
\text { deposit }\end{array}$ & 11 & 1 & 0 & $\mathbf{2 4 \%}$ \\
\hline $\begin{array}{l}\text { Faculty members have responsibility to } \\
\text { deposit their works }\end{array}$ & 7 & 2 & 0 & $\mathbf{1 8 \%}$ \\
\hline
\end{tabular}

\section{Discussion}

\section{Institutional Demographics}

Institutions considering or in the process of gathering support for an open access policy should be encouraged by the demographic data collected from respondents. The survey data shows institutions with and without a medical school, with varying faculty body sizes, and with variable federal research budgets have successfully pursued open access. For example, institutions with less than 250 and more than 3,000 faculty members have passed policies. In terms of annual federal grant funding, policies have been established at institutions with less than $\$ 1$ million and more than $\$ 500$ million. Having positive facultyadministration relations and a system of shared governance in place appears to be helpful, although certainly not detrimental if absent. The presence of negative or mixed relations between faculty and administration may simply necessitate more work on the part of advocates to overcome concerns or misunderstandings regarding open access policymaking.

\section{Policy Types}

With respect to the policy types that institutions have pursued, the data indicate a tendency to gravitate toward two very different policy types: a Harvard style policy that automatically grants a nonexclusive license and a related expectation of deposit in an institutional repository; or a policy statement that encourages faculty to make their scholarship accessible through open access. In some ways, these two approaches represent ends of a spectrum. While the Harvard style model lacks compliance mechanisms, it is an institutional policy that specifically articulates what faculty members are "required" to do, while statements of encouragement have less policylike features and explicit expectations. Also, in the Harvard model, the entire faculty is automatically covered by the policy; individuals must opt out if they do not want to participate, while statements of encouragement are based on a general opt-in approach. 
For those institutions seeking a more formal and prescriptive policy, the Harvard model is the standard that most respondents chose to employ. This is likely driven in part by the extensive guidelines created at Harvard for best practices in open access policy development. These guidelines have been employed by a number of institutions to create Harvard-style policies, and the collective momentum created by this ongoing sequence of adoptions has presumably enabled the Harvard approach to gain widespread traction as well.

Besides policy type, policy coverage is another consideration for institutions. The rationale behind most of the survey respondents who chose an institutionwide policy may be based on two factors: a policy that covers all faculty has the potential for making a larger amount of scholarship accessible via open access than departmental or college level policies; and there has been a ripple effect of institutional policies being successfully implemented at universities such as MIT, Duke, and the University of Kansas that are held up as models for emulation within the open access community. While the process for passing such policies at the institutional level may be more challenging from the logistical and political perspectives, most schools appear to be taking this route to facilitate the widest dissemination of their faculties' scholarship.

Passing policies at the departmental or college level, however, can set the stage for eventual passage of an institutionwide policy. For example, open access policies at Oregon State University were passed independently by the faculties of the University Libraries, College of Forestry, and College of Ocean and Atmospheric Sciences in the years preceding passage of a universitywide policy by the faculty senate. Institutional and department/college policies are not mutually exclusive; they may be part of a larger progression within a university.

\section{Policy Waivers and Embargoes}

The survey results demonstrate that the standard approach for establishing open access policies at universities and colleges is for faculty members to pass these policies for themselves. This fact has significance on multiple levels. It suggests that faculty members who voted at the Enacted Policy institutions widely recognize the value of open access with regard to their scholarship. As more institutions pass Harvard-style open access policies in particular, they reflect a growing culture of open access in which faculty members formally establish expectations for article manuscript deposit as partand-parcel of publishing research at their respective institutions. In the process, most existing institutional open access policies seek to balance these expectations with faculty freedom to choose their level of participation via waivers or embargoes. As the open access policy landscape matures over time, it will be important to monitor if waivers and embargoes were necessary concessions to faculty choice in the early phases of passing open access policies that will ultimately fade away in light of a stronger commitment in academia to open access as the default setting for scholarly communication.

Since the dominant Harvard-style policy is based on the deposit of faculty articles into an institutional repository, it seems open access policies are pursued largely to increase the number of articles that are made openly accessible via institutional repositories. However, in policies that grant a nonexclusive license to the institution, it is standard practice to allow faculty members to request and automatically receive waivers from the policy. The issue of waivers has stimulated extensive debate in the open access community. Some view the waivers as essential for respecting academic freedom and enabling policies to be passed by faculty bodies, while others consider waivers a feature that significantly dilutes the power of open access policies.

For example, in his book Open Access, Peter Suber observes, "We could say that rights-retention policies require OA except when authors opt out, or that they simply 
shift the default to OA. Those are two ways of saying the same thing because, either way, faculty remain free to decide for or against OA for each of their publications. Preserving this freedom and making it conspicuous help muster faculty support, indeed, unanimous faculty votes." 14 Open access advocate Michael Eisen counters this perspective in reference to the University of California system open access policy: "This policy has a major, major hole-an optional faculty opt-out. This is there because enough faculty wanted the right to publish their works in ways that were incompatible with the policy that the policy would not have passed without the provision. Unfortunately, this means that the policy is completely toothless. It provides a ready means for people to make their works available-which is great. And having the default be open is great. But nobody is compelled to do it in any meaningful way - therefore it is little more than a voluntary system." In the same blog post, Eisen goes on to note that some major publishers are now requiring authors from institutions with open access policies to get a waiver to publish in their journals. ${ }^{15}$

The challenge of writing and implementing open access policies in ways that address the interests of institutions, faculty authors, and publishers is also illustrated in the issue of publisher embargoes. In response to authors' interest in depositing their work into repositories, and the growing number of open access policies at the institutions that employ researchers and from the funding agencies that underwrite research, many publishers have developed embargo policies that seek to limit when the open access versions can be made publicly accessible. These embargoes generally range from six to twenty-four months after the date of publication. Publisher embargoes should not be confused with the rights of faculty authors to self-embargo their articles within an institutional repository, which is allowed by the policies in a majority of the Enacted Policy and In Process groups. It should be noted that observation of publisher embargoes is rarely articulated in the language of an open access policy. The decision to honor these embargoes is typically an element of the implementation of the policy, which is usually led by the library as manager of the institutional repository.

\section{Policy Promotion}

Libraries assume a lead role in initiating open access policies but often assume a more supporting but still important role in promoting the policy and educating faculty colleagues on open access. Survey data indicate multiple promotion and communications strategies that should be considered when pursuing enactment of an open access policy. In offering various rationales to faculty for the importance of open access, there was a divergence among the respondent groups on the issues of the journal pricing crisis and open access requirements by funding agencies, with the Enacted Group focusing more on the former than the latter, and the opposite being true for the In Process Group. This reflects an evolution in the open access landscape. While the price of scholarly journals remains a major problem for academic institutions, explanations of the benefits of open access seem to currently focus less on the issue of combating journal subscription costs and more on the collective impact of scholarship being disseminated through various open methods. The trend of increasing open access requirements from funding agencies is reflected in the emphasis placed on this issue by the In Process Group, and that argument will likely increase in relevance over time as more agencies establish open access requirements.

Another interesting dichotomy that arose in the responses to questions on policy promotion was the popularity of panels, forums, brochures, and the like as promotional tools; yet skepticism was also voiced by respondents as to their effectiveness. One respondent commented that the "endless discussions and debate, panels, forums, brochures, [and] web sites" did not matter because the proponents were on board and 
the minds of the detractors could not be changed. Another comment expressed that the website and other printed information were not "key to the OA policy process." Rather, "face to face meetings were the heart and soul of the process." Yet another comment shared that active promotion was not necessary for passage of a policy at that institution, indicating that the policy passed "with very little promotion or education of faculty." Finally, some respondents from the Enacted Policy Group indicated that open forums were poorly attended.

The most effective method of promotion among respondents involved engagement with governance groups. Numerous institutions in both the Enacted Policy and the In Process groups described promotion efforts that heavily involved presentations and other engagement with faculty senates, academic councils, and other governance bodies. The following comments were shared by respondents about the importance of governance engagement:

- "We met with as many campus governance groups as would agree to hear us out."

- "Communication happened primarily within the faculty senate."

- "Presentations to the faculty senate and faculty senate executive committee... began the process."

- "The task force got on the agenda of the Faculty Senate Executive Committee. The task force proposed that the Executive Committee consider putting an open access policy on the faculty senate agenda. The Executive Committee suggested a timeline and course of action for writing a policy and getting it in front of faculty.... A draft of the policy was made available on the faculty senate web page and faculty senators were asked to review it and take it back to their units for discussion."

\section{Faculty Concerns and Responses}

During policy promotion, respondents observed several common concerns raised by faculty. The most frequent concerns pertained to the presumed burden placed upon faculty to comply with the policy and a perception of institutional coercion or control via the policy. The perception of burden can be alleviated through both education and library services to support the deposit of faculty articles. Proponents of a policy as well as those involved with managing the institution's repository should make it clear how simple the steps are for depositing works. The benefits of a nonexclusive license as granted to institutions in rights retention or Harvard-style policies should also be emphasized.

Respondents are addressing the perception of burden with offers of deposit assistance and reducing duplication of effort through harvesting articles from existing repositories when possible. Given the frequency with which faculty express concern that complying with an open access policy will pose a burden, it is important that libraries and others charged with managing the repository and administering implementation of a policy give sufficient thought to how deposit will be structured and supported in advance of promoting a policy. Having an article identification and submission workflow in place can help assuage faculty fears.

Faculty perception of institutional coercion and control may best be addressed through the language of the policy itself. This often stems from the use of the word "mandate" or "mandatory," despite the complete lack of enforcement mechanisms to ensure faculty compliance. Suber addresses this issue in his book Open Access, stating: “Unfortunately, we don't have a good vocabulary for policies that use mandatory language while deferring to third-person dissents or first-person opt-outs....The word "mandate" is not a very good fit for policies like this, but neither is any other English 
word." Further, a policy that is a faculty-led initiative approved by a governing body or that involves faculty from across disciplines can help with combating the perception of institutional coercion. Other vocalized concerns by faculty are best addressed in the promotional messages and education being done by open access policy proponents. Messages of reassurance about retention of copyright, choice of publication venue, and the availability of waivers demonstrate respect for the needs and rights of faculty authors and an absence of institutional coercion and control.

\section{Keys to Success}

The best guidance for open access policy development may come in the form of direct advice from those who have enacted such policies. Respondents in the Enacted Policy Group were asked an additional question in the survey: "What do you believe were the keys to success to the passage of the open access policy?" This question did not have any preset answers; instead, it offered respondents the opportunity to describe in their own words what they believed to be the keys to success at their institutions. Common themes emerged from their replies, some of which echo results from other questions in the survey:

Libraries often propose the initial concept of an open access policy and are instrumental supporters of them, but they also need nonlibrary faculty to assume lead roles in promoting the policies. Faculty buy-in is more likely to result from peer-to-peer advocacy for the policy than from library exhortations. Within this context, the involvement of widely respected faculty advocates who work in tandem with the library on policy development and promotion was deemed essential for success.

As supporters of open access policy development and promotion, librarians must be able to succinctly articulate the policy's benefits, confidently address any questions raised by faculty, and engage in nuanced discussion about the policy and its ramifications. While it is important to have nonlibrary faculty leading much of the promotion process, librarians typically have deeper expertise on open access issues and policy details so they must be prepared to serve as resident experts in campus discussions. Associated with this role is the shared view that an empathic approach to addressing faculty concerns was essential for guiding the dialogue toward a positive outcome.

Libraries should develop a policy implementation strategy in advance of policy promotion to assure faculty that the policy will not create an unreasonable burden on them. There is a sense that, while many faculty members may support the general principle of open access, they will not approve a policy if they believe it will create too much additional work for them. Libraries are skilled at designing effective implementation strategies and must convincingly communicate these plans to inform the cost-benefit analysis that many faculty members will undertake to determine their individual level of support for the policy.

The open access policies passed thus far appear to universally lack any enforcement mechanisms, and multiple respondents noted this as a key to the policies' passage by faculty. There is a commonly held view that faculty are more likely to support an open access policy if it does not contain any form of coercion that would ensure their compliance. This relates to another frequent observation in the survey responses that it is important for the policy to be viewed as "nonthreatening" to faculty. While that approach may help to ensure policy passage, it also raises questions of how this may limit a policy's impact, if there should be formal enforcement mechanisms, and what those might entail.

The keys to success articulated in the survey results offer sound guidance for those considering open access policies, and they also raise issues that merit further research. 
The question of how to best ensure comprehensive faculty compliance across campus seems to be an area that is especially relevant for future studies.

\section{Conclusion}

As more educational institutions establish open access policies, there is a corresponding need to assess how these policies are created as well as their individual and collective impact on improving access to faculty scholarship. This article tackled the first issue by analyzing the results of a survey of fifty-one North American institutions that have pursued open access policies. In capturing the policy development and promotion experiences of a broad range of institutions, this study lays a foundation on which subsequent examination of the impact of these policies can be developed. While the academic library community seems to generally accept open access policies as a "good thing," there is a critical need to measure the tangible impact of institutional policies to determine their true value.

In the meantime, institutions continue to pursue open access policies as evidenced by regular announcements of new policies being passed at a variety of universities and colleges. In this environment, cross-institutional studies will take on even greater importance to document their collective ramifications for scholarly communication. Just as they have been leaders in conceiving and advocating for institutional open access policies, academic libraries are well positioned to carry out further research on the policies as they mature over time. 


\section{Appendix. Open Access Policy Formation Survey}

This survey should be answered by the person who is most familiar with the open access policy drafting and/or adoption process at your institution. It may or may not be someone affiliated with your institution's library. North American institutions who have adopted, who are in the process of drafting, or who have attempted and failed to adopt an open access policy at the institutional, college, or departmental level should respond to this survey. By "open access policy," we include all policy types, including deposit mandates, rights retention policies, "opt-in" policies, and statements of encouragement or support of open access. Through your responses, we will analyze how open access policies have been developed and promoted across academic institutions in North America, as well as the factors that may have influenced the adoption or rejection of particular types of open access policies. This study will further document the institutional open access policy movement in North America. We plan to share our findings widely through groups such as the Coalition of Open Access Policy Institutions (COAPI) as well as through conference presentations and a journal article. We believe the results of the survey will be especially helpful to institutions that plan to develop open access policies in the future. Your survey response is essential to the success of this project and its potential impact. The survey will take approximately 30 minutes to complete and should be completed by September 19, 2014. This survey is composed primarily of multiple-choice and a few short-answer questions. You have the option of identifying yourself and your institution by name but such identification is not required. The survey was designed by Christine Fruin, Scholarly Communications Librarian at the University of Florida, with Shan Sutton, Associate University Librarian for Research and Scholarly Communication at Oregon State University. Any questions about completing the survey should be directed to Christine Fruin. Thank you.

\subsection{What is the name of your institution? (Optional)}

1.2 If you are willing to be contacted for a follow-up interview, please provide your contact information below:

Name

E-mail

Telephone

1.3 Is your institution public or private?

O Public

O Private

1.4 Is your institution a land-grant college or university? (A land-grant college or university is an institution that has been designated by its state legislature or Congress to receive the benefits of the Morrill Acts of 1862 and 1890.)
○ Yes
O No

1.5 What degrees does your institution offer? Choose all that apply.

O Bachelors

O Masters

O Doctorate ( $\mathrm{PhD}$ or equivalent)

O Medicine (MD or equivalent)

- Law (JD or equivalent)

O Dentistry (DDS or equivalent)

Veterinary Medicine (DVM or equivalent) 
1.6 How many full-time faculty are employed by your institution?

O 100 or fewer

O 101-249

O $250-499$

O $500-749$

O $750-999$

O $1,000-1,499$

O $1,500-1,999$

O $2,000-2,499$

O $2,500-2,999$

O 3,000 or more

1.7 Are your institution's faculty members covered by a collective bargaining agreement? O Yes

O No

1.8 Does your institution participate in shared governance?

O Yes

O No

1.9 How would you characterize the relationship between your institution's administration and its faculty?

1.10 Does your institution have a Library Committee composed of faculty members outside the library that provides advice and guidance on library issues?

O Yes

O No

1.11 What is the average annual amount of federal grant funding for academic research received by faculty at your institution?

Less than $\$ 250,000$

○ $\$ 250,000$ to $\$ 500,000$

O $\$ 500,000$ to $\$ 1,000,000$

○ $\$ 1$ million to $\$ 5$ million

○ $\$ 5$ million to $\$ 10$ million

O $\$ 10$ million to $\$ 50$ million

- $\$ 50$ million to $\$ 100$ million

O \$100 million to $\$ 250$ million

O \$250 million to $\$ 500$ million

O More than $\$ 500$ million

O Unknown

1.12 Is your institution a signatory to the Berlin Declaration on Open Access to Knowledge in the Sciences and Humanities?

O Yes

O No

2.1 Does your institution currently have an enacted open access policy at the university, individual college or department level? Please answer yes if there is currently an enacted policy, regardless of policy type.

Y Yes (You will be taken to Section 3 of the survey.)

O No 
2.2 If no, what is the current status of open access policy adoption at your institution?

- We are currently in the process of drafting an open access policy and are gathering input from campus constituents on how the policy should be drafted. (You will be taken to Section 4 of the survey.)

- We have an open access policy draft and are gathering support from campus constituents for the policy as drafted. (You will be taken to Section 4 of the survey.)

O We have attempted to pass an open access policy but the initiative failed. (You will be taken to Section 5 of the survey.)

3.1 Who does your open access policy apply to?

All faculty

O Only select colleges or departments

3.2 What colleges or departments does your institution's open access policy apply to? Check all that apply.
$\square$ College of Liberal Arts and Sciences
$\square \quad$ College of Medicine
$\square$ College of Public Health
$\square \quad$ Libraries
$\square$ Other(s) (please list)

3.3 Through what process was the open access policy enacted?

O Faculty senate (or equivalent) vote

O Administrative action

O College or departmental vote

O Other (please explain)

3.4 What type of open access policy was adopted at your institution? (Definitions from "Good Practices for University Open-Access Policies" edited by Stuart Shieber and Peter Suber.)

O Policy grants, without action by the author, the institution certain nonexclusive rights (a pre-existing license) to future research articles published by faculty and offers a waiver or an opt-out for authors. The policy also requires deposit in the institutional repository.

O Policy requires faculty to negotiate with publishers to retain certain nonexclusive rights in their articles including the right to deposit their articles in the institutional repository.

O Policy seeks no rights at all but requires faculty to deposit future articles in the institutional repository. Deposits will be available immediately upon deposit if institution has permission from author to make it available open access. Otherwise, deposit will be dark.

O Policy seeks no rights at all and requires deposit in the institutional repository and open access availability only when the publisher permits it.

O Policy is merely a statement of encouragement to publish future works open access.

O Policy does not require open access but asks faculty to "opt in" to the practice of self-archiving and open access.

O If your policy is of a type not described here, or is a blend of two or more of these policy types, please detail below the general conditions of the policy enacted at your institution: 
3.5 If your policy includes a waiver, please select the conditions that apply:

$\square$ Waiver may be obtained or is granted without proof of justification or need.

$\square$ Waiver requests approved with proof of justification or need.

$\square$ Waiver only applies to the license or permission granted to the institution, not to the deposit in the repository.

$\square$ Waiver applies to both the license or permission granted to the institution and the deposit requirement.

$\square \quad$ Waiver only applies to a single article.

$\square$ Waiver applies to all articles by the author.

3.6 Does your policy allow authors to delay open availability of the article after it is deposited (embargo)?
○ Yes

O No

3.7 Are publisher embargoes on public access to deposited manuscripts observed?

O Yes

O No

In some cases (please explain)

3.8 Please describe how the idea of an open access policy arose at your institution. Please include who or what body first raised the idea of adopting an open access policy.

3.9 Who had responsibility for promoting the open access policy and growing consensus for its support before it was formally adopted? Names are not necessary, but titles or departmental affiliations would be useful.

3.10 What, if any, external supports or resources were used in promoting an open access policy at your institution? (some examples: publications, outside consultants)

3.11 Please describe the process employed for promoting and growing consensus for support of an open access policy at your institution. Include examples of what types of communication or promotional materials were used (some examples: open forums, panels, brochures, websites).

3.12 How much time was spent on educating faculty and other constituents about open access and the impact of an open access policy before the policy was presented for formal adoption?

L Less than 6 months

O 6-12 months

O 1-2 years

O More than 2 years

3.13 Prior to passing an open access policy, was there an active program soliciting faculty members to deposit the final peer-reviewed manuscripts of their published articles into the institutional repository?

O Yes

O No 
3.14 If yes, did the rate of faculty deposits increase after the passage of the open access policy?

O Yes

○ No

3.15 What reasons were offered in conversations with faculty and other constituents about why open access is important? Check all that apply.

$\square$ Open access enables authors to retain more of their rights in their own work rather than assigning all rights to the publishers.

$\square$ Open access is a means of addressing the pricing crisis in subscription scholarly journals and combating the monopoly that a few publishers have on the dissemination of scholarship.

$\square$ Open access promotes access to research by anyone. It allows more people to benefit from scholarship (including the general public, who may have an interest in or need for scholarly research).

$\square$ Open access allows faculty to not only be better researchers but also better educators. When professors can't access the most recent research, they are deprived of the opportunity to bring that material into the classroom. With science advancing at an ever-increasing pace, it's crucial that professors have access to cutting-edge research, so students' education is not outdated before they even finish a course.

$\square$ Open access facilitates collaboration on new research. With access barriers removed, scientists and other researchers can share scholarship across borders and work together more efficiently to bring forth new ideas.

$\square$ Open access supports public access. A large body of scholarship is funded through public tax dollars, and the public should be allowed free and unburdened access to the research they help support.

$\square$ Scholarly research can be made open access through deposit in open access repositories (green OA) or through publication in open access journals (gold OA). Publication of scholarly research in gold OA journals does not signify that the research is of lesser quality. Gold OA scholarly literature is not lesser quality than traditionally published scholarship. Much of the open access literature published via gold OA is subject to the same or more rigorous peer review as traditional toll access journals.

$\square$ Open access supports the institution's land-grant mission.

$\square$ Open access supports the institution's education and/or research mission.

$\square$ Open access enables access to research by scholars at institutions that cannot afford access to the subscription-based journals in which the articles are published, especially those in non-Western countries.

$\square$ Open access to research outputs is becoming a standard requirement at many funding agencies.

$\square \quad$ Other (Please detail below.)

$\square$ We didn't discuss with faculty and other constituents the importance of open access.

3.16 What concerns or questions were most frequently raised by faculty and others before the open access policy was formally adopted? Check all that apply.

$\square \quad$ Requirement of multiple deposits where funder policy also requires deposit of a work in an open access repository.

$\square$ Complying with the policy will create a burden on faculty in terms of work involved in depositing articles in institutional repository or requesting waivers.

$\square$ Questions about copyright ownership under policy, including concern that greater control being transferred to institution and that deposit in institutional repository permits unauthorized use of works by others. 
$\square$ Confusion as to what types of publications the policy applies, including questions about what is meant by "scholarly journal articles."

$\square$ Belief that policy requires publication in open access journals only.

$\square$ Confusion about difference between "gold OA" and "green OA" and difference between place of publication versus requirement of deposit.

$\square$ Publishers will refuse to publish their work if they are subject to an open access policy.

$\square$ Open access policy infringes upon academic freedom.

$\square$ If policy framed as a mandate, fear of institutional control or coercion.

$\square$ Open access will hurt scholarly societies.

$\square$ Other questions or concerns raised (please list)

3.17 What responses were given in reply to questions or concerns raised by faculty and others about the adoption of an open access policy at your institution? Check all that apply.

$\square$ The version of the article to be deposited in the institutional repository is the final version of the peer-reviewed manuscript. The published version should not be deposited unless expressly allowed by the publisher but a link to the published version should be provided when a manuscript is deposited.

$\square \quad$ The policy does not require publication in any particular type of journal; publication in any journal is acceptable as long as the final peer-reviewed version of the article is deposited in the institutional repository.

$\square \quad$ If a publisher refuses to publish an article because of the policy, a waiver is readily available to the faculty member.

$\square \quad$ Waivers are available without proof or justification of need.

$\square$ Copyright ownership of a faculty member's work is not being transferred to the institution; rather, the institution is merely given a nonexclusive license. Under the policy, authors retain more rights to and control over their work than through standard publishing agreements.

$\square$ The policy only applies to scholarly journal articles published after the enactment of the policy and does not apply to creative works, monographs, or other royaltygenerating works.

$\square$ Assistance is available for deposit of article manuscripts in the institutional repository.

$\square$ Faculty members have responsibility for depositing their own article manuscripts in the institutional repository.

$\square \quad$ If the article has been deposited in another open access repository (such as PubMed Central), the institution will harvest that copy for deposit in the institutional repository.

$\square$ Faculty members may specify an embargo period (delay the visibility of their works in the institutional repository).

$\square$ The benefits of depositing works in the institutional repository include inclusion in search engine indexing leads to greater discoverability of works, greater exposure to researchers and readers who can access the openly and freely available content, interoperability with other repositories, and permanent safe archive for scholarly works.

$\square$ The library will track the publication of articles by faculty and request the final peer-reviewed manuscripts from faculty.

$\square \quad$ Other (Please detail below.)

3.18 If a faculty vote was taken to adopt an open access policy, how close was the vote?

Unanimous in support

Large majority of votes in support (more than $90 \%$ of votes cast) 
A majority of votes in support (between $60 \%-90 \%$ of votes cast)

- A slight majority of votes in support (between $51 \%-59 \%$ of votes cast)

3.19 Does your institution have a fund supporting publication in open access journals?

○ Yes

O No

3.20 What do you believe were the keys to success to the passage of the open access policy?

4.1 To whom will the proposed open access policy apply?

All faculty

O Only select colleges or departments

4.2 What colleges or departments will the proposed open access policy apply to? Choose all that apply.
$\square$ College of Liberal Arts and Sciences
$\square$ College of Medicine
$\square$ College of Public Health
L Libraries
$\square$ Other(s) (please list)

4.3 Please describe how the idea of an open access policy arose at your institution. Please include who or what body first raised the idea of adopting an open access policy.

4.4 Who has responsibility for promoting an open access policy and growing consensus for its support at your institution? Names are not necessary, but titles or department affiliations would be helpful.

4.5 What, if any, external supports or resources are being used in promoting an open access policy at your institution? (some examples: publications, outside consultants)

4.6 Please describe how an open access policy has been promoted and support sought at your institution. Include examples of what types of communication or promotional materials have been or are planned to be used (some examples: open forums, panels, brochures, websites).

4.7 Is there currently an active program soliciting faculty members to deposit the final peer-reviewed manuscripts of their published articles into the institutional repository? O Yes

O No

4.8 What reasons have been offered in conversations with faculty and other constituents about why open access is important? Check all that apply.

$\square$ Open access enables authors to retain more of their rights in their own work rather than assigning all rights to the publishers.

$\square$ Open access is a means of addressing the pricing crisis in subscription scholarly journals and combating the monopoly that a few publishers have on the dissemination of scholarship.

$\square$ Open access promotes access to research by anyone. It allows more people to benefit from scholarship, including the general public who may have an interest in or need for scholarly research. 
$\square$ Open access allows faculty to not only be better researchers but also better educators. When professors can't access the most recent research, they are deprived of the opportunity to bring that material into the classroom. With science advancing at an ever-increasing pace, it's crucial that professors have access to cutting-edge research, so students' education isn't outdated before they even finish a course.

$\square$ Open access facilitates collaboration on new research. With access barriers removed, scientists and other researchers can share scholarship across borders and work together more efficiently to bring forth new ideas.

$\square$ Open access supports public access. A large body of scholarship is funded through public tax dollars, and the public should be allowed free and unburdened access to the research they help support.

$\square$ Scholarly research can be made open access through deposit in open access repositories (green OA) or through publication in open access journals (gold OA). Publication of scholarly research in gold OA journals does not signify that the research is of lesser quality. Gold OA scholarly literature is not lesser quality than traditionally published scholarship. Much of the open access literature published via gold $\mathrm{OA}$ is subject to the same or more rigorous peer review as traditional toll access journals.

$\square$ Open access supports the institution's land-grant mission.

$\square$ Open access supports the institution's education and/or research mission.

$\square$ Open access enables access to research by scholars at institutions that cannot afford access to the subscription-based journals in which the articles are published, especially those in non-Western countries.

$\square$ Open access to research outputs is becoming a standard requirement at many funding agencies.

$\square \quad$ Other (Please detail below.)

$\square$ We haven't discussed the importance of open access with faculty and other constituents.

4.9 What concerns or questions have been raised by faculty and others about the adoption of an open access policy at your institution? Check all that apply.

$\square$ Requirement of multiple deposits where funder policy also requires deposit of a work in an open access repository.

$\square$ Complying with the policy will create a burden on faculty in terms of work involved in depositing articles in institutional repository or requesting waivers.

$\square$ Questions about copyright ownership under policy, including concern that greater control being transferred to institution and that deposit in institutional repository permits unauthorized use of works by others.

$\square$ Confusion as to what types of publications the policy applies, including questions about what is meant by "scholarly journal articles."

$\square$ Belief that policy requires publication in open access journals only.

$\square$ Confusion about difference between "gold OA" and "green OA" and difference between place of publication versus requirement of deposit.

$\square$ Publishers will refuse to publish their work if they are subject to an open access policy.

$\square$ Open access policy infringes upon academic freedom.

$\square$ If policy framed as a mandate, fear of institutional control or coercion.

$\square$ Open access will hurt scholarly societies.

$\square$ Other questions or concerns raised (please list)

$\square$ We haven't begun discussing an open access policy with faculty and others yet. 
4.10 What responses have been given in reply to questions or concerns raised by faculty and others about the adoption of an open access policy at your institution? Check all that apply.

$\square \quad$ The version of the article to be deposited in the institutional repository is the final version of the peer-reviewed manuscript. The published version should not be deposited unless expressly allowed by the publisher, but a link to the published version should be provided when a manuscript is deposited.

$\square \quad$ The policy does not require publication in any particular type of journal; publication in any journal is acceptable as long as the final peer-reviewed version of the article is deposited in the institutional repository.

$\square \quad$ If a publisher refuses to publish an article because of the policy, a waiver is readily available to the faculty member.

$\square \quad$ Waivers are available without proof or justification of need.

$\square$ Copyright ownership of a faculty member's work is not being transferred to the institution; rather, the institution is merely given a nonexclusive license. Under the policy, authors retain more rights to and control over their work than through standard publishing agreements.

$\square \quad$ The policy only applies to scholarly journal articles published after the enactment of the policy and does not apply to creative works, monographs, or other royaltygenerating works.

$\square$ Assistance is available for deposit of article manuscripts in the institutional repository.

$\square$ Faculty members have responsibility for depositing their article manuscripts in the institutional repository.

$\square \quad$ If the article has been deposited in another open access repository (such as PubMed Central), the institution will harvest that copy for deposit in the institutional repository.

$\square \quad$ Faculty members may specify an embargo period (delay the visibility of their works in the institutional repository).

$\square \quad$ The benefits of depositing works in the institutional repository include inclusion in search engine indexing leads to greater discoverability of works, greater exposure to researchers and readers who can access the openly and freely available content, interoperability with other repositories, and permanent safe archive for scholarly works.

$\square \quad$ The library will track the publication of articles by faculty and request the final peer-reviewed manuscripts from faculty.

$\square \quad$ Other (Please detail below)

$\square$ We haven't begun conversations with faculty and others.

4.11 How much time do you plan to spend on educating faculty and other constituents about open access and the impact of an open access policy before the policy is presented for formal adoption?

Less than 6 months

O 6-12 months

O 1-2 years

O More than 2 years

4.12 What type of open access policy has been drafted or may be drafted based upon feedback received so far? (Definitions from "Good Practices for University Open-Access Policies" edited by Stuart Shieber and Peter Suber.)

O Policy grants, without action by the author, the institution certain nonexclusive rights (a pre-existing license) to future research articles published by faculty and offers a waiver or an opt-out for authors. The policy also requires deposit in the institutional repository. 
Policy requires faculty to negotiate with publishers to retain certain nonexclusive rights in their articles including the right to deposit their articles in the institutional repository.

O Policy seeks no rights at all but requires faculty to deposit future articles in the institutional repository. Deposits will be available immediately upon deposit if institution has permission from author to make it available open access. Otherwise, deposit will be dark.

O Policy seeks no rights at all and requires deposit in the institutional repository and open access availability only when the publisher permits it.

O Policy is merely a statement of encouragement to publish future works open access.

- Policy does not require open access but asks faculty to "opt in" to the practice of self-archiving and open access.

O If the policy your institution is considering is a type not described here, or is a blend of two or more of these policy types, please detail below the general conditions of the policy enacted at your institution:

4.13 If your policy draft will include a waiver, please select the conditions that will apply:

$\square$ Waiver may be obtained or is granted without proof of justification or need.

$\square$ Waiver requests approved with proof of justification or need.

$\square$ Waiver only applies to the license or permission granted to the institution, not to the deposit in the repository.

$\square$ Waiver applies to both the license or permission granted to the institution and the deposit requirement.

$\square \quad$ Waiver only applies to a single article.

$\square$ Waiver applies to all articles by the author.

4.14 Will your policy draft allow authors to delay the open availability of the article after it is deposited (embargo)?

O Yes

O No

O Undecided

4.15 Will your policy draft observe publisher embargoes on public access to deposited manuscripts?
O Yes
O No
In some cases (please explain)
O Undecided

4.16 How likely do you think it is that an open access policy will be adopted at your institution?
O Very Unlikely
O Unlikely
O Somewhat Unlikely
O Undecided
O Somewhat Likely
O Likely
○ Very Likely 
4.17 When do you think an open access policy will be brought forward for formal adoption?

O Within the next 6 months

Within the next 6-12 months

In a year or more

4.18 Through what process will the open access policy be presented for formal adoption?

F Faculty senate (or equivalent) vote

O Administrative action

O College or departmental vote

Other (please explain)

5.1 Who did your open access policy draft apply to?

All faculty

O Only select colleges or departments

5.2 What colleges or departments did your institution's open access policy draft apply to? Check all that apply.

$\square$ College of Liberal Arts and Sciences

$\square \quad$ College of Medicine

$\square$ College of Public Health

$\square$ Libraries

$\square$ Other(s) (please list)

5.3 Through what process was the open access policy presented for adoption?

O Faculty senate (or equivalent) vote

O Administrative action

O College or departmental vote

O Other (please explain)

5.4 What type of open access policy was proposed at your institution? (Definitions from "Good Practices for University Open-Access Policies" edited by Stuart Shieber and Peter Suber.)

Policy granted, without action by the author, the institution certain nonexclusive rights (a pre-existing license) to future research articles published by faculty and offers a waiver or an opt-out for authors. The policy also required deposit in the institutional repository.

O Policy required faculty to negotiate with publishers to retain certain nonexclusive rights in their articles including the right to deposit their articles in the institutional repository.

O Policy sought no rights at all but required faculty to deposit future articles in the institutional repository. Deposits will be available immediately upon deposit if institution has permission from author to make it available open access. Otherwise, deposit will be dark.

O Policy sought no rights at all and required deposit in the institutional repository and open access availability only when the publisher permits it.

- Policy was merely a statement of encouragement to publish future works open access.

O Policy did not require open access but asked faculty to "opt in" to the practice of self-archiving and open access.

- If your policy was of a type not described here, or was a blend of two or more of these policy types, please detail below the general conditions of the policy voted on at your institution: 
5.5 If your policy draft included a waiver, please select the conditions that applied:

- Waiver would be obtained or be granted without proof of justification or need.

Waiver requests approved with proof of justification or need.

- Waiver only applied to the license or permission granted to the institution not to the deposit in the repository.

- Waiver applied to both the license or permission granted to the institution and the deposit requirement.

Waiver only applied to a single article.

Waiver applied to all articles by the author.

5.6 Did your policy draft allow authors to delay open availability of the article after it was deposited (embargo)?

O Yes

O No

5.7 Prior to proposing an open access policy, was there an active program soliciting faculty members to deposit the final peer-reviewed manuscripts of their published articles into the institutional repository?

O Yes

O No

5.8 Please describe how the idea of an open access policy arose at your institution. Please include who or what body first raised the idea of adopting an open access policy.

5.9 Who had responsibility for promoting the open access policy and growing consensus for its support before it was presented for a vote? Names are not necessary, but titles or department affiliations would be useful.

5.10 What, if any, external supports or resources were utilized in promoting an open access policy at your institution? (examples: publications, outside consultants)

5.11 Please describe the process employed for promoting and growing consensus for support of an open access policy at your institution. Include examples of what types of communication or promotional materials were used (some examples: open forums, panels, brochures, websites).

5.12 How much time was spent on educating faculty and other constituents about open access and the impact of an open access policy before the policy was presented for adoption?

Less than 6 months

O 6-12 months

O 1-2 years

O More than 2 years

5.13 What reasons were offered in conversations with faculty and others about why open access is important? Check all that apply.

$\square$ Open access enables authors to retain more of their rights in their own work rather than assigning all rights to the publishers.

$\square$ Open access is a means of addressing the pricing crisis in subscription scholarly journals and combating the monopoly that a few publishers have on the dissemination of scholarship. 
$\square$ Open access promotes access to research by anyone. It allows more people to benefit from scholarship, including the general public who may have an interest in or need for scholarly research.

$\square$ Open access allows faculty to be not only better researchers but also better educators. When professors can't access the most recent research, they are deprived of the opportunity to bring that material into the classroom. With science advancing at an ever-increasing pace, it's crucial that professors have access to cutting-edge research, so students' education is not outdated before they even finish a course.

$\square$ Open access facilitates collaboration on new research. With access barriers removed, scientists and other researchers can share scholarship across borders and work together more efficiently to bring forth new ideas.

$\square$ Open access supports public access. A large body of scholarship is funded through public tax dollars, and the public should be allowed free and unburdened access to the research they help support.

$\square$ Scholarly research can be made open access through deposit in open access repositories (green OA) or through publication in open access journals (gold OA). Publication of scholarly research in gold OA journals does not signify that the research is of lesser quality. Gold OA scholarly literature is not lesser quality than traditionally published scholarship. Much of the open access literature published via gold OA is subject to the same or more rigorous peer review as traditional toll access journals.

$\square$ Open access supports the institution's land-grant mission.

$\square$ Open access supports the institution's education and/or research mission.

$\square$ Open access enables access to research by scholars at institutions that cannot afford access to the subscription-based journals in which the articles are published, especially those in non-Western countries.

$\square$ Open access to research outputs is becoming a standard requirement at many funding agencies.

$\square$ Other (please detail below)

$\square$ We didn't discuss with faculty and other constituents the importance of open access.

5.14 What concerns or questions were most frequently raised by faculty before the open access policy was presented for a vote? Check all that apply.

$\square$ Requirement of multiple deposits where funder policy also requires deposit of a work in an open access repository.

$\square$ Complying with the policy will create a burden on faculty in terms of work involved in depositing articles in institutional repository or requesting waivers.

$\square$ Questions about copyright ownership under policy, including concern that greater control being transferred to institution and that deposit in institutional repository permits unauthorized use of works by others.

$\square$ Confusion as to what types of publications the policy applies, including questions about what is meant by "scholarly journal articles."

$\square$ Belief that policy requires publication in open access journals only.

$\square$ Confusion about difference between "gold OA" and "green $\mathrm{OA}^{\text {" }}$ and difference between place of publication versus requirement of deposit.

$\square$ Publishers will refuse to publish their work if they are subject to an open access policy.

$\square$ Open access policy infringes upon academic freedom.

$\square$ If policy framed as a mandate, fear of institutional control or coercion.

$\square$ Open access will hurt scholarly societies.

$\square$ Other questions or concerns raised (please list) 
5.15 What responses were given in reply to questions or concerns raised by faculty and others about the adoption of an open access policy at your institution? Check all that apply. $\square$ The policy does not require publication in any particular type of journal; publication in any journal is acceptable as long as the article is deposited in the institutional repository.

$\square \quad$ If a publisher refuses to publish an article because of the policy, a waiver is readily available to the faculty member.

$\square \quad$ Waivers are available without proof or justification of need.

$\square$ Copyright ownership of a faculty member's work is not being transferred to the institution; rather, the institution is merely given a nonexclusive license. Under the policy, authors retain more rights to and control over their work than through standard publishing agreements.

$\square$ The policy only applies to scholarly journal articles published after the enactment of the policy and does not apply to creative works, monographs, or other royalty generating works.

$\square$ Assistance is available for deposit of articles in the institutional repository.

$\square$ Faculty members have responsibility for depositing their articles in the institutional repository.

$\square$ If the article has been deposited in another open access repository (for instance, PubMed Central), the institution will harvest that copy for deposit in the institutional repository.

$\square$ The version of the article to be deposited in the institutional repository is the final version of the peer-reviewed manuscript. The published version should not be deposited unless expressly allowed by the publisher, but a link to the published version should be provided when a manuscript is deposited.

$\square \quad$ Faculty members may specify an embargo period (delay the visibility of their works in the institutional repository).

$\square$ The benefits of depositing works in the institutional repository include inclusion in search engine indexing leading to greater discoverability of works, greater exposure to researchers and readers who can access the openly and freely available content, interoperability with other repositories, and permanent safe archive for scholarly works.

$\square$ The library will track the publication of articles by faculty and request the final peer-reviewed manuscripts from faculty.

$\square \quad$ Other (please detail below)

5.16 In your opinion, why do you think your institution failed to adopt an open access policy?

5.17 Do you think that your institution will again attempt to adopt an open access policy?

O Yes

O Unsure

O No

5.18 Does your institution have a fund supporting publication in open access journals?

O Yes

O No

6.1 If you have any additional information or comments you'd like to share, please do so below. 


\section{Notes}

1. National Institutes of Health, NIH Public Access Policy Details, available online at http:// publicaccess.nih.gov/policy.htm [accessed 1 May 2015].

2. Harvard University Library, Harvard Faculty of Arts and Sciences Open Access Policy, available online at https://osc.hul.harvard.edu/hfaspolicy [accessed 1 May 2015].

3. California Taxpayer Access to Publicly Funded Research Act (AB 609), available online at http://www.leginfo.ca.gov/cgi-bin/postquery?bill_number=ab_609\&sess=CUR [accessed 1 May 2015]; Illinois Open Access to Articles Act (SB 1900), available online at http://www.ilga.gov/ legislation/BillStatus.asp?DocNum=1900\&GAID=12\&DocTypeID=SB\&LegID=\&SessionID=85\&Sp ecSess $=\& S e s s i o n=\& G A=98$ [accessed 1 May 2015]; New York Taxpayer Access to Publicly Funded Research Legislation (A180-2013 and S4050-2013), available online at http://open.nysenate.gov/ legislation/api/1.0/lrs-print/bill/S4050-2013 [accessed 1 May 2015].

4. MIT Faculty Open Access Policy, available online at http://libraries.mit.edu/scholarly/mitopen-access/open-access-at-mit/mit-open-access-policy/ [accessed 1 May 2015]; Duke University Open Access Policy for Faculty Scholarship, available online at http://library.duke.edu/research/ openaccess [accessed 1 May 2015]; Open Access Policy for the Academic Senate of the University of California, available online at http://osc.universityofcalifornia.edu/open-access-policy/policytext/ [accessed 1 May 2015].

5. Coalition of Open Access Policy Institutions, available online at http://www.sparc.arl.org/ COAPI [accessed 1 May 2015].

6. Good Practices for University Open Access Policies, available online at http://cyber.law. harvard.edu/hoap/Good_practices_for_university_open-access_policies [accessed 1 May 2015].

7. Xia Jingfeng et al., "A Review of Open Access Self-Archiving Mandate Policies," portal: Libraries \& The Academy 12 (2012): 85-102, doi:10.1353/pla.2012.0000.

8. Ada Emmett et al., "Toward Open Access: It Takes a 'Village,'” Journal of Library Administration 51 (2011): 557-79, doi:10.1080/01930826.2011.589345.

9. Kevin Smith, "Why Open Access? The Policy Environment and Process on One University Campus," Insights: The UKSG Journal 25 (2012): 246-50, doi:10.1629/2048-7754.25.3.246.

10. Shannon Kipphut-Smith, "Engaging in a Campus-Wide Conversation about Open Access," Texas Library Journal 90 (2014): 70-71.

11. Shannon Kipphut-Smith, "'Good Enough': Developing a Simple Workflow for Open Access Policy Implementation," College \& Undergraduate Libraries 21 (2014): 279-94, doi:10.1080/106 91316.2014.932263.

12. Brian Kern and Susan Wishnetsky, "Adopting and Implementing an Open Access Policy: The Library's Role," Serials Librarian 66 (2014): 196-203, doi:10.1080/0361526X.2014.880035.

13. In the survey instructions, respondents were given the option whether they wanted to identify the institution they were reporting on, and the authors assured anonymity for those who did identify.

14. Peter Suber, Open Access (Boston: MIT Press 2012), 82.

15. Michael Eisen, "Let's Not Get Too Excited about the New UC Open Access Policy," it is NOT junk (blog), August 2, 2013, available online at www.michaeleisen.org/blog/?p=1413 [accessed 1 May 2015]. 